\title{
Variation in the planktonic larval duration of the temperate wrasse Semicossyphus pulcher
}

\author{
Robert K. Cowen
}

Marine Sciences Research Center, State University of New York, Stony Brook, New York 11794-5000, USA

\begin{abstract}
Recently settled juveniles of the temperate wrasse Semicossyphus pulcher were studied for evidence of patterns in otolith microstructure corresponding to developmental stages. Fish collected at settlement were found to range in age from 37 to $78 \mathrm{~d}$, yet size only ranged from 12.7 to $16.0 \mathrm{~mm}$. Examination of otolith increment width, used as a measure of daily growth, revealed 2 patterns: (1) fish with long larval lives (e.g. 50 to 78 d) had an abrupt slowing of growth after ca 35 to 37 d in the plankton, with continued slow growth until settlement; and (2) fish that settled early (e.g. 35 to 40 d) had no evidence of slow growth. It would appear that 35 to $37 \mathrm{~d}$ is the minimum development period (i.e. precompetent period) required for this species. In addition, little variation occurred in the duration of the precompetent phase relative to the duration of the slow-growth, competent period. Post-settlement growth was unaffected by the duration of the larval life, regardless of the presence of the slow-growth phase, suggesting that extended competent phases are not detrimental to the fish. Constraints on the larvae to delay metamorphosis may be related to the need to find a suitable settlement site within the appropriate stage of their development. A longer precompetent phase may require a longer competent period to ensure that the larvae encounter a settlement site.
\end{abstract}

\section{INTRODUCTION}

Most marine fish have complex life histories that include a pelagic larval stage. This life history strategy, which is dispersive in nature, has resulted in a variety of requisite adaptations to ensure survival during this developmental stage. As larvae, fish are components of the zooplankton community and are subject to patchy food sources and a variety of predators. While response to availability of prey and avoidance of predation are typically shared by all larval fish species, some larval fish can be classified by their survival requirements at the end of their larval stage. For example, the larvae of reef-dwelling fish must be transported to a suitable settlement site at the appropriate stage in their development whereas the larvae of pelagic fish are already within their adult habitat.

During larval development, certain morphological and physiological systems must develop prior to metamorphosis. Development can therefore be classified into 2 distinct stages (drawing from invertebrate terminology): the first, 'precompetency', corresponds to the phase in which the larva is developing up to the point of being capable of metamorphosis, and the second, 'competency', corresponds to the phase where metamorphosis may occur given the right cues. Because larval reef fish have the additional constraint of returning to a settlement site, the timing of metamorphosis is probably related not only to developmental stage, but also to stimuli associated with the appropriate settlement sites. Response to settlement sites has been demonstrated for many invertebrate species (Crisp 1974, Scheltema 1977, Strathmann 1978, Butman 1987). Recent work has suggested that at least some reef fish may be selecting their settlement sites via behavioral or chemical cues (Sweatman 1988) in response to the presence of algae (Jones 1984, Carr 1989), conspecifics (Sweatman 1983) or other fish species (Jones 1987, Sweatman 1990).

Larval duration of reef fishes has been shown to vary considerably within a species (Brothers et al. 1983, Victor 1986a, b, Fowler 1989, Thresher et al. 1989, Wellington \& Victor 1989), and may be the result of several processes acting on each of the 2 stages of larval development (Victor 1986b). During the precompetent stage, development may depend on growth rate which in turn is affected by environmental features such as food availability and temperature. Once a larva has reached competency, metamorphosis may be delayed due to a lack of suitable settlement cues. 
Depending on in which stage of development most of this variation occurs, information may be gained about the processes responsible for the observed variance in larval duration. If the main cause of variation is due to processes acting during the precompetent stage, then the same degree of variation in the length of the precompetent stage should occur as in the total larval duration. Alternatively, if the variation in the total duration of larval life is primarily due to processes acting after competency is achieved, then most of the variation should occur in the length of this stage, with relatively little variation occurring in the length of the precompetent stage. Finally, environmental conditions may affect both developmental stages resulting in some intermediate condition.

The purpose of this study was to verify the onset of competency in the California sheephead Semicossyphus pulcher and to delineate the source of variation observed in the duration of larval life. A primary question is whether the observed variation in the length of larval life is due to variation in the rate of development in the precompetent stage or the result of the larva's ability to delay metamorphosis during the competency period. Additionally, the consequences of delayed growth during the competent period on later, post-settlement growth were examined.

\section{METHODS}

California sheephead were collected at 2 sites in California, USA, a coastal site off La Jolla $\left(117^{\circ} 15^{\prime} \mathrm{W}\right.$, $32^{\circ} 45^{\prime} \mathrm{N}$ ), and an offshore island site at San Nicolas Island $\left(119^{\circ} 28^{\prime} \mathrm{W}, 33^{\circ} 12^{\prime} \mathrm{N}\right)$. Some fish were collected within $2 \mathrm{~d}$ of settlement at both sites, others were collected at varying times after the settlement event (30 to $60 \mathrm{~d})$ at the San Nicolas Island site. The fish were collected with dip nets and the anaesthetic Quinaldine and placed in $95 \%$ ethanol.

In the laboratory, the standard length (SL) of each fish was measured to the nearest $0.1 \mathrm{~mm}$. The otoliths (sagitta and lapillus) were extracted from the fish, placed on a glass slide and glued in place with a drop of fingernail hardener. The otolith analysis procedures followed those of Brothers (1987), with only the sagitta used in this analysis. When needed, the otoliths were hand-polished on 600 and 1200 grit emery cloth with periodic viewing under a compound microscope to monitor progress until the primordium was exposed. Analysis of the otoliths was done on a video-equipped compound microscope using a $400 \times$ objective. The video image was enhanced with a computer-aided image analysis software package (BIOSONICS, Inc., Optical Pattern Recognition System, Seattle, WA). Of 62 fish collected, 29 had otolith increments clear enough for counting. Of these, 11 were from recently settled fish $(<2 \mathrm{~d})$ and 18 were collected up to $50 \mathrm{~d}$ after settlement. Increments were counted from the otolith's focus to its outer edge. Increment width was measured along a single radius. Whenever possible, this radius was selected to correspond to the greatest possible radius. In the few cases where that portion of the otolith was unreadable, another radius was chosen and measurements were standardized to the longest radius. A total of 11 of the above 29 fish had increments clear enough for measurement of daily increment width along one radius. The position of the settlement check (conspicuous transition in the increments formed at the time of settlement) was also noted.

The daily nature of otolith increments in Semicossyphus pulcher has been previously verified (Cowen 1985). Briefly, juveniles were collected at the San Nicolas site during the settlement event and $30 \mathrm{~d}$ later. The increments laid down after the settlement check were then counted and compared to the number of days since the settlement event. There was a one-toone correspondence between increments laid down after settlement and days since the settlement event (Cowen 1985). Two days were added to the total counts to account for the time between fertilization and the deposition of daily increments as being typical of labrids (Fritzche 1978, Victor 1982).

Back-calculating daily growth rates from increment width assumes a constant, positive relationship between otolith size and somatic growth. However, this relationship has recently been shown to vary as a result of metabolic conditions of the larvae (Mosegaard et al. 1988, Secor \& Dean 1989, Reznick et al. 1989, Hovenkamp 1990). In this study, a positive, though not necessarily constant, relationship is assumed to exist between otolith growth and somatic growth.

To estimate the mean pre-settlement growth of individuals collected after settlement, the mean length at settlement (i.e. of those fish collected at settlement) was divided by the number of days to the settlement mark. While this method underestimates the growth rate of those fish that were late settlers since their actual length at settlement would be greater than the mean, these late settlers also demonstrated a reduced growth rate prior to settlement (see 'Results') which minimized the difference. Post-settlement growth of individuals collected after settlement was estimated from the regression of length at capture against the number of days since settlement, as determined by the number of increments laid down after the settlement mark.

\section{RESULTS}

There is considerably more variance in the age at settlement than in size at settlement. The size at settle- 

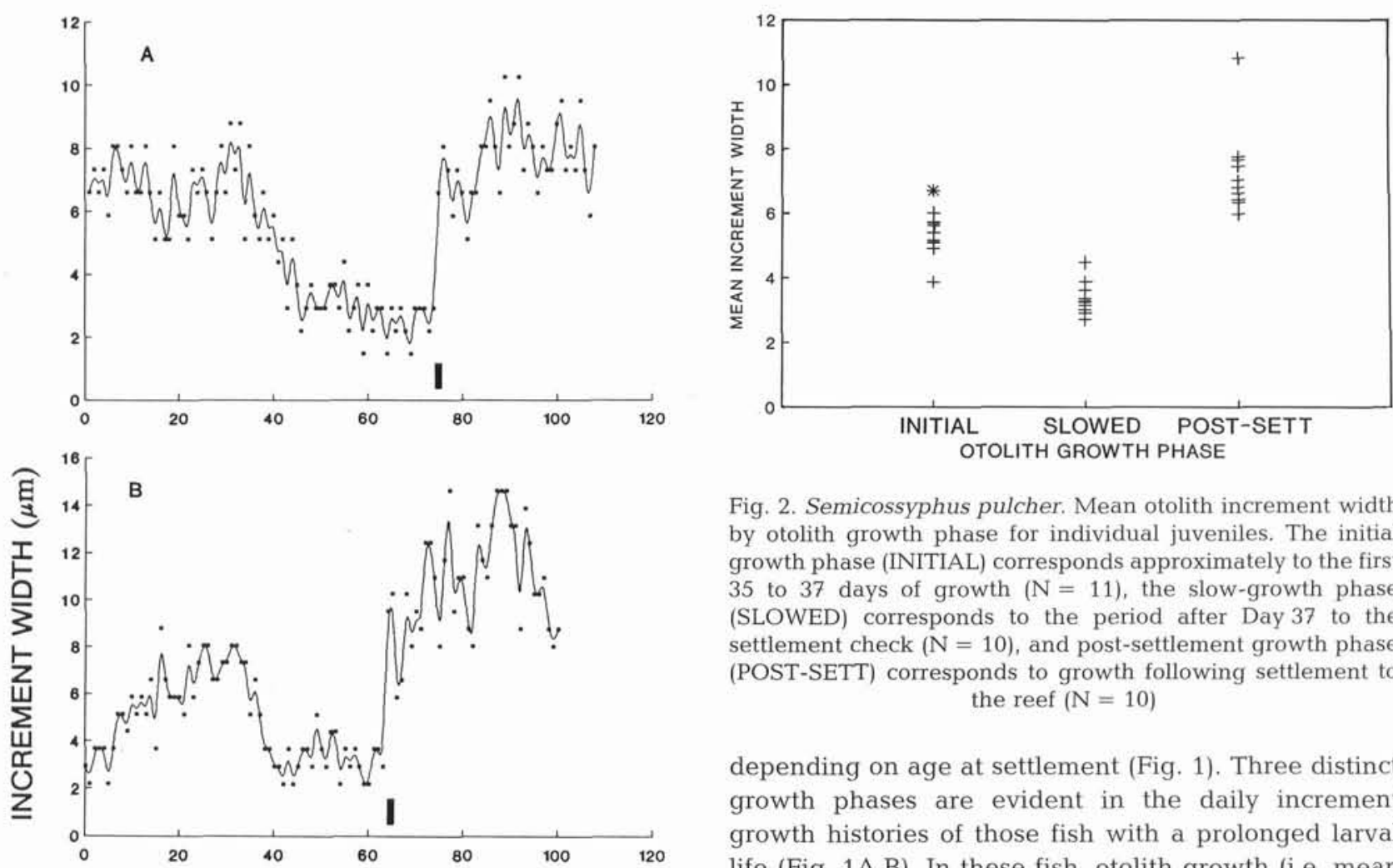

Fig. 2. Semicossyphus pulcher. Mean otolith increment width by otolith growth phase for individual juveniles. The initial growth phase (INITIAL) corresponds approximately to the first 35 to 37 days of growth $(\mathrm{N}=11)$, the slow-growth phase (SLOWED) corresponds to the period after Day 37 to the settlement check $(\mathrm{N}=10)$, and post-settlement growth phase (POST-SETT) corresponds to growth following settlement to the reef $(\mathrm{N}=10)$

depending on age at settlement (Fig. 1). Three distinct growth phases are evident in the daily increment growth histories of those fish with a prolonged larval life (Fig. 1A,B). In these fish, otolith growth (i.e. mean otolith increment width) proceeded at about 6 to $8 \mu \mathrm{m}$ $\mathrm{d}^{-1}$ for approximately the first 35 to $37 \mathrm{~d}$, then slowed abruptly to 2 to $4 \mu \mathrm{m} \mathrm{d}^{-1}$. This slow-growth phase continued until settlement (e.g. 63 d, Fig. 1A; 76 d, Fig. 1B). Following settlement, otolith growth increased rapidly to between 6 and $12 \mu \mathrm{m} \mathrm{d}^{-1}$. Growth rates for fish with a relatively short larval life, however, remained relatively high with no evidence of a slowgrowth phase (Fig. 1C). In these fish, settlement occurred at about the time ( $37 \mathrm{~d}$ ) that slow-growth began in fish with longer larval duration (Fig. 1C).

Plotting mean increment width by growth phase for each fish further demonstrates the pattern of distinct slowing that occurred when settlement was not coincident with the completion of the initial growth phase (Fig. 2). In all fish examined except one, either a slowing of growth or settlement occurred at 35 to $41 \mathrm{~d}$. In the one exception, the growth rate was higher than any of the other fish examined $\left(6.8 \mu \mathrm{m} \mathrm{d}^{-1}\right)$ and slowing began on Day 30 (datum point denoted with an asterisk, Fig. 2).

Variation in larval duration was primarily accounted for within the slow-growth phase rather than the initial growth phase [Fig. 3; variance ratio test (Zar 1984), F = $22.1, \mathrm{p}<0.001]$. The initial growth phase ranged from 30 to $41 \mathrm{~d}$, with most falling between 35 and $38 \mathrm{~d}[\overline{\mathrm{X}}=$ $36.5 \mathrm{~d}$, Coefficient of Variation $(\mathrm{CV})=7.77 \mathrm{~J}$. In comparison, the duration of the slow-growth phase varied from zero, where the fish apparently settled as soon as

Daily growth patterns varied among individuals 


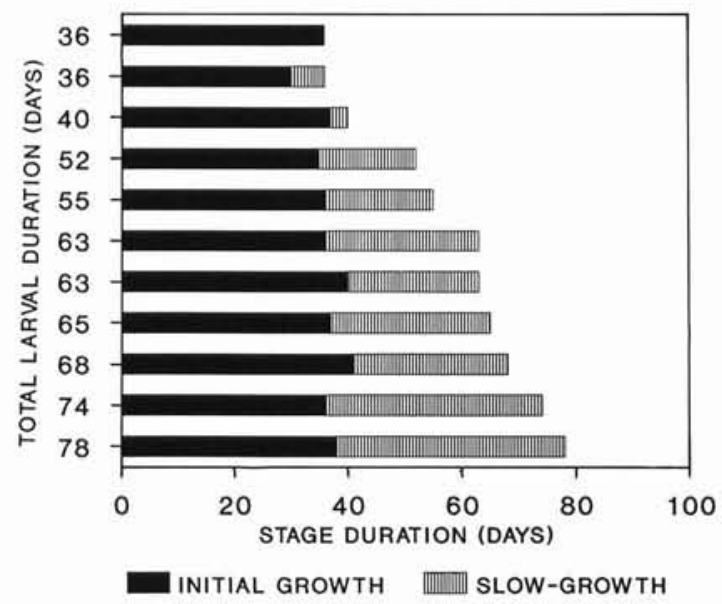

Fig. 3. Semicossyphus pulcher. Duration (d) of initial growth phase and slow-growth phase of individual post-settled juveniles

competency was attained, to a maximum of $40 \mathrm{~d}(\overline{\mathrm{X}}=$ $20.7 \mathrm{~d}, \mathrm{CV}=64.46)$. Total larval durations ranged from 37 to $78 \mathrm{~d}$.

Mean pre-settlement growth rates ranged from 0.16 to $0.35 \mathrm{~mm} \mathrm{~d}^{-1}$. The fastest mean growth rates occurred in those fish which settled at the youngest age since all fish were of similar size at settlement; older individuals experienced a longer period of reduced growth, thus they grew at an apparently slower mean rate. Following settlement, the mean growth rate was $0.55 \mathrm{~mm} \mathrm{~d}^{-1}$ $\left[\mathrm{SL}=12.4+0.55\right.$ (Days since settlement), $\mathrm{r}^{2}=0.9, \mathrm{n}=$ 19; slope significantly different from zero, $t=13.75$, $\mathrm{p}<0.001]$. There was no negative effect of delayed metamorphosis on post-settlement growth rates; in fact, there was a slight, positive relationship between post-settlement growth rates and the duration of the larval stage $\left(\mathrm{Y}=0.07+0.006 \mathrm{X}, \mathrm{r}^{2}=0.43, \mathrm{n}=11\right.$; slope significantly different from zero, $\mathrm{t}=2.54, \mathrm{p}<0.05$ ).

\section{DISCUSSION}

Previous workers have shown that a variety of life history stages are evident in the microstructure of otoliths (e.g. Brothers \& McFarland 1981, Victor 1982, Radtke 1989, Fowler 1989). In the present study, the occurrence of either a settlement mark or reduced otolith growth at about 35 to 37 d suggests that competency was achieved at this age. Apparently, if a larva was in the vicinity of an appropriate settlement site following the completion of its precompetent development, settlement occurred. In contrast, if conditions were inappropriate for settlement, metamorphosis was delayed, thus prolonging larval duration. This prolonged larval duration was physically evident by an associated slowing of otolith growth during the compe- tent stage of development. Victor (1986b) noted a similar response of slowed growth during the delay of metamorphosis in another labrid, Thalassoma bifasciatum. Of particular interest in the present study is the relatively small variance observed in the duration of the precompetent period relative to the competent period.

The range of ages at settlement for Semicossyphus pulcher was large in the present study (35 to $78 \mathrm{~d}$ ) relative to that found by Victor (1986a; Table 1, 34 to $52 \mathrm{~d})$. While this may reflect differences in sample size, it is perhaps representative of the varied distances of the sampling sites from concentrated sources of larvae of $S$. pulcher. The youngest $S$. pulcher at settlement in this study and that of Victor (1986a) were collected from habitats within the central portion of the range of Califiornia sheephead and therefore close to larval sources. On the other hand, the fish with older settlement ages (in the present study) were collected at San Nicolas Island, an offshore island where there are generally no upstream sources of larval California sheephead and recruitment occurs only during occasional shifts in the dominant flow patterns which bring larvae from relatively distant sources (Cowen 1985). Such data suggest that the mean age at settlement may provide some insight as to how far away larval sources are (Victor 1986a), and observed variance in ages at settlement may indicate multiple sources of larvae at varying distances from the settlement site.

The ability to delay metamorphosis, and thereby extend larval duration, conveys several possible advantages to the larvae. It has been argued that long pelagic larval lives are selected for as a result of the need to disperse the young (Scheltema 1977, Barlow 1981). Yet there is a lack of evidence supporting the patterns predicted by such theories (Palmer \& Strathmann 1981, Strathmann 1985, Thresher \& Brothers 1985, Thresher et al. 1989, Wellington \& Victor 1989). While dispersal may be aided by the presence of extended larval durations, it may not be the major selective factor influencing larval duration. More importantly, a strategy to enhance dispersal would not necessarily require an ability to delay metamorphosis; longer developmental times in the precompetent stage would accomplish the same result. Regardless of the driving forces behind the strategy of having a pelagic stage (e.g. increased availability of food for young larvae, reduced threat of predation over reefs, improved dispersal), an important provision of that strategy must be to ensure that the larva can eventually return to the reef habitat.

An advantage of the capacity to delay metamorphosis is the flexibility to settle when a suitable settlement site is presented, or more importantly, when such a site is not available, to continue to survive until such a site is located (Jackson \& Strathmann 1981, Cowen 


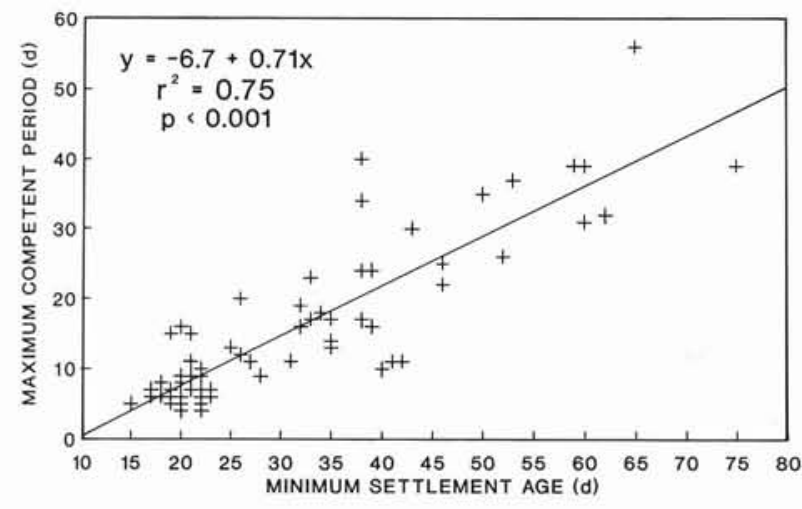

Fig. 4. Estimate of the relationship between the length of the precompetent stage and the potential length of the competent stage in 73 species of labrids. The minimum age of settlement was used to estimate the length of the precompetent period. The potential duration of the competent stage was calculated from the difference between the minimum age at settlement and the maximum age at settlement. Data are from Victor (1986a); only those species with sample sizes of $\geq 10$ were included in this analysis

1985, Victor 1986b). Jackson \& Strathmann (1981) proposed that finding a suitable settlement cue is important in the evolution of delayed metamorphosis in many invertebrate larvae. They proposed a connection between the time required to reach competency and the amount of time that metamorphosis can be delayed, arguing that the longer the precompetent stage, the greater the chance of being carried away from a settlement site and therefore the longer the time in the competent stage required to encounter a suitable site. This hypothesis predicts that species with a long precompetent stage will have a potentially long competent stage. A reanalysis of Victor's (1986a) data supports this (Fig. 4). Assuming that the minimum age at settlement is a first order estimate of the length of the precompetent stage, and that the maximum range of age at settlement is a first order estimate of the duration of the competent stage, there is a significant positive relationship for 73 species of labrids between the duration of the precompetent stage and that of the competent stage. While the results of such an analysis are preliminary, they are suggestive. Some of the observed relationship may be caused by variable growth rates, and hence development rates, thereby affecting the age at which competency is achieved (i.e. the minimum age at settlement may vary). Yet, unless all larvae are settling upon achieving competency, and the results of this study as well as Victor (1986b) suggest otherwise, a component of the above relationship must result from variation in the duration of the competent period. Thus it appears, at least for labrids, that a long precompetent stage may be accompanied by a relatively long competent stage.
Longer competent periods convey the advantage of increasing the larvae's likelihood of being present during short duration (days to weeks) circulation events favorable to onshore transport (Cowen 1985). If, on the average, a short-term (say 2 to $3 \mathrm{~d}$ ), onshore circulation event (e.g. wind event, squirt, jet, internal wave slick) occurs once a month, the species whose competent stage extends for $4 \mathrm{wk}$ will have a far greater chance of utilizing such a transport event than a species whose competent stage is only $1 \mathrm{wk}$. As a result, recruitment success would probably be enhanced for those species with a longer competent stage in the larval life, at least partially compensating for any negative effects of longer larval duration (e.g. additional time larvae are exposed to predation).

Associated with the prolonged larval duration was an apparent slowing of growth of the larvae. Somatic growth may be uncoupled from otolith growth (Mosegaard et al. 1988, Reznick et al. 1989, Secor \& Dean 1989, Hovenkamp 1990), even to the extent that when somatic growth is negative some minimum amount of $\mathrm{CaCO}_{3}$ is still deposited on the otoliths (Marshall \& Parker 1982, Jones \& Brothers 1987). In this regard, differences in otolith growth must be indicative of even greater differences in somatic growth (Hovenkamp 1990). While the actual daily rate of somatic growth (i.e. measured as standard length) could not be determined, the otolith data demonstrate that relative somatic growth rates were much lower during the competent stage than in the precompetent and post-settlement stages.

Several questions remain regarding the constraints and/or advantages of an extended competency period with reduced growth rate. Not all fish species with long larval stages necessarily reduce their growth once competency is achieved. Some may continue to grow as evidenced by some very large individual larvae of some pleuronectids (Pearcy et al. 1977) and bothids (R. Cowen pers. obs.), while other species have actually developed specialized larval stages for prolonged larval durations (e.g. the acronura stage of the Acanthurids). For some fish, however, such as the California sheephead in this study, certain physiological and morphological constraints may limit the ability of the larval fish to grow beyond a certain size. For example, the configuration of the digestive tract of the larva may only be efficient or large enough to support a larva's growth up to a given size; changes associated with metamorphosis may be required to grow beyond that size (e.g. allometric changes in the size of the digestive system relative to the body size).

Delayed metamorphosis due to reduced growth during the competent period is distinct from a prolonged larval duration due to slowed growth resulting from poor environmental conditions (e.g. food and tempera- 
ture; Chambers \& Leggett 1987, Chambers et al. 1988). In this study, most of the fish studied achieved competency within 35 to $37 \mathrm{~d}$. In the one case where competency was apparently achieved several days earlier (at ca 30 d) mean increment widths reflect a faster growth rate during this individual's precompetent stage as compared to the others. Since competency is a stage in the development of the fish, environmental factors affecting growth would be expected to affect the age at which competency is achieved rather than the length of the competent period. This could be verified by examining interannual variation in the age at which competency is achieved and/or by examining larvae from different regions within the species range in a given year. Within the range of the California sheephead, water temperatures can vary by as much as 5 to $8^{\circ} \mathrm{C}$, which would likely have a significant effect on growth rates and consequently developmental rates.

Once settlement and metamorphosis occurred, growth rates increased dramatically. This increase can apparently more than compensate for the delayed period, accounting for the observed positive relationship. While this slight positive relationship between larval duration and post-settlement growth rates may not have any biological basis, it is possible that, though growth is significantly reduced during the competency stage, it still results in slightly larger fish at settlement which may then attain feeding and/or growth advantages. Further work is needed for verification.

Finally, the need to find a suitable settlement site within a certain window of time in the development of the larvae represents a critical period in a larval reef fish's life. Delaying metamorphosis extends the window of time in which the larvae may find a settlement site, thereby enhancing their chances of settling. The trade-off to extending the duration of the larval stage is the longer period of time the larva will be exposed to potentially high predation rates (Houde 1987). Ultimately settlement is just as critical to its survival as that of finding food or avoiding predators. Labrids appear to have relatively long-lived larvae with considerable variation in the duration of their larval lives relative to other families of tropical reef fish (Brothers et al. 1983, Thresher \& Brothers 1985, Victor 1986a, Thresher et al. 1989, Wellington \& Victor 1989). Species with shorter larval durations such as Pomacentrids may also have a proportionately similar plasticity in the duration of their competent stage, but more detailed study is needed to identify such trends. If larval duration is related to the utilization of transport and/or retention processes, then the difference in larval duration between groups such as labrids and pomacentrids may reflect differences in the physical mechanisms used by larvae for transport to or retention within the vicinity of reef habitat (e.g. Thresher \& Brothers 1989). Species with less restrictive settlement site requirements (e.g. shelf or slope species) may not need as large of a window for settlement. Extending this to the extreme case of pelagic species where no specific habitat is needed for settlement and metamorphosis, little variation in the duration of the larval stage due to transport or retention requirements would be expected. Any variation occurring would probably be due to environmental factors (e.g. food availability and temperature) influencing the growth rate within the 'precompetent' stage. In other words, there is no a priori reason for pelagic species (those already in their adult habitat) to have the ability to delay metamorphosis.

Acknowledgements. I thank S. Sponaugle, J. Hare, T. Present and R. Cerrato for discussion and/or critical reviews of the manuscript. L. Chiarella helped with the preparation of the otoliths. Comments from 3 anonymous reviewers also contributed to the final preparation of this paper.

\section{LITERATURE CITED}

Barlow, G. W. (1981). Patterns of parental investment dispersal and size among coral-reef fishes. Environ. Biol. Fish. 6: 65-85

Brothers, E. B. (1987). Methodological approaches to the examination of otoliths in aging studies. In: Summerfeldt, R.C., Hall, G. E. (eds.) Age and growth of fish. Iowa State Univ. Press, Des Moines, p. 319-330

Brothers, E. B., McFarland, W. N. (1981). Correlations between otolith microstructure, growth, and life history transitions in newly recruited French grunts (Haemulon flavolineatum Desmarest: Haemulidae). Rapp. P.-v. Réun. cons. int. Explor. Mer 178: 369-374

Brothers, E. B., Williams, D. McB., Sale, P. F. (1983). Length of larval life in twelve families of fishes at 'One Tree Lagoon', Great Barrier Reef, Australia. Mar. Biol. 76: 319-324

Butman, C. A. (1987). Larval settlement of soft-sediment invertebrates: the spatial scales of pattern explained by active habitat selection and the emerging role of hydrodynamical processes. Oceanogr. mar. biol. A. Rev. 25: 113-165

Carr, M. H. (1989). Effects of macroalgal assemblages on the recruitment of temperate zone reef fishes. J. exp. mar. Biol. Ecol. 126: 59-76

Chambers, R. C., Leggett, W. C. (1987). Size and age at metamorphosis in marine fishes: an analysis of laboratoryreared winter flounder (Pseudopleuronectes americanus) with a review of variation in other species. Can. J. Fish. Aquat. Sci. 44: 1936-1947

Chambers, R. C., Leggett, W. C., Brown, J. A. (1988). Variation in and among early life history traits of laboratory-reared winter flounder Pseudopleuronectes americanus. Mar. Ecol. Prog. Ser. 47: 1-15

Cowen, R. K. (1985). Large scale pattern of recruitment by the labrid, Semicossyphus pulcher: causes and implications. J. mar. Res. 43: 719-742

Crisp, D. J. (1974). 5. Factors influencing the settlement of marine invertebrate larvae. In: Grant, P. T., Mackie, A. M. (eds.) Chemoreception in marine organisms. Academic Press, New York, p. 177-265

Fowler, A. J. (1989). Description, interpretation and use of the 
microstructure of otoliths from juvenile butterflyfishes (family Chaetodontidae). Mar. Biol. 102: 167-181

Fritzche, R. A. (1978). Development of fishes of the MidAtlantic Bight. Vol. 5. U.S. Dept. Int., Washington D.C.

Houde, E.D. (1987). Fish early life dynamics and recruitment variability. Am. Fish. Soc. Symp. 2: 17-29

Hovenkamp, F. (1990). Growth differences in larval plaice Pleuronectes platessa in the Southern Bight of the North Sea as indicated by otolith increments and RNA/DNA ratios. Mar. Ecol. Prog. Ser. 58: 205-215

Jackson, G. A., Strathman, R. R. (1981). Larval mortality from offshore mixing as a link between precompetent and competent period of development. Am. Nat. 118: 16-26

Jones, C., Brothers, E. B. (1987). Validation of the otolith increment technique for striped bass, Morone saxatilis, larvae reared under suboptimal feeding conditions. Fish. Bull. U.S. 85 : $171-178$

Jones, G. P. (1984). Population ecology of the temperate reef fish Pseudolabrus celidotus Bolch and Schneider (Pisces: Labridae). I. Factors influencing recruitment. J. exp. mar. Biol. Ecol. 75: 257-276

Jones, G. P. (1987). Competitive interactions among adults and juveniles in a coral reef fish. Ecology 68: 1534-1547

Marshall, S. L., Parker, S. S. (1982). Pattern identification in the microstructure of sockeye salmon (Oncorhynchus nerka) otoliths. Can. J. Fish. Aquat. Sci. 39: 542-547

Mosegaard, H., Svedang, H., Taberman, K. (1988). Uncoupling of somatic and otolithic growth rates in Arctic char (Salvelinus alpinus) as an effect of differences in temperature response. Can. J. Fish. Aquat. Sci. 45: 1514-1524

Palmer, A. R., Strathmann, R. R. (1981). Scale of dispersal in varying environments and its implications for life histories of marine invertebrates. Oecologia (Berl.) 48: 308-318

Pearcy, W. G., Hosie, M. J., Richardson, S. L. (1977). Distribution and duration of pelagic life of larvae of Dover sole, Microstomus pacificus; rex sole, Glyptocephalus zachirus; and petrale sole, Eopsetta jordani, in waters off Oregon. Fish. Bull. U.S. 75: 173-183

Radtke, R. L. (1989). Larval fish age, growth, and body shrinkage: information available from otoliths. Can. J. Fish. Aquat. Sci. 46: 1884-1894

Reznick, D., Linbeck, E., Bryga, H. (1989). Slower growth results in larger otoliths: an experimental test with guppies (Poecilia reticulata). Can. J. Fish. Aquat. Sci. 46: 108-112

Scheltema, R. S. (1977). Dispersal of marine invertebrate organisms: paleobiogeographic and biostrategraphic

This article was submitted to the editor implications. In: Kauffman, E. G., Hazel, J. E. (eds.) Concepts and methods in biostratigraphy. Dowden, Huchinson and Ross, Stroudburg, p. 73-108

Secor, D. H., Dean, J. M. (1989). Somatic growth effects on the otolith-fish size relationship in young pond-reared striped bass, Morone saxatilis. Can. J. Fish. Aquat. Sci. 46: 113-121

Strathmann, R. R. (1978). Larval settlement in echinoderms. In: Chia, F. S., Rice, M. E. (eds.) Settlement and metamorphosis of marine invertebrate larvae. Elsevier, New York

Strathmann, R. R. (1985). Feeding and nonfeeding larval development and life-history evolution in marine invertebrates. Ann. Rev. Ecol. Syst. 16: 339-361

Sweatman, H. (1983). Influence of conspecifics on choice of settlement sites by larvae of two pomacentrid reef fishes (Dascyllus aruanus and D. reticulatus) on coral reefs. Mar. Biol. 75: 225-229

Sweatman, H. (1988). Field evidence that settling coral reef fish larvae detect resident fishes using dissolved chemical cues. J. exp. mar. Biol. Ecol. 124: 163-174

Sweatman, H. (1990). Effects of selective settlement and of aggression by residents on distribution of young recruits of two tropical damselfishes. Mar. Biol. 105: 247-252

Thresher, R. E., Brothers, E. B. (1985). Reproductive ecology and biogeography of Indo-West Pacific angelfishes (Pisces: Pomacanthidae). Evolution 39: 878-887

Thresher, R. E., Brothers, E. B. (1989). Evidence of intra- and inter-oceanic regional differences in the early life history of reef-associated fishes. Mar. Ecol. Prog. Ser. 57: 187-205

Thresher, R. E., Colin, P. L., Bell, L. J. (1989). Planktonic duration, distribution and population structure of western and central Pacific damselfishes (Pomacentridae). Copeia 1989 (2): 420-434

Victor, B. C. (1982). Daily otolith increments and recruitment in two coral reef wrasses, Thalassoma bifasciatum and Halichoeres bivittatus. Mar. Biol. 71: 203-208

Victor, B. C. (1986a). Duration of the planktonic larval stage of one hundred species of Pacific and Atlantic wrasses (family Labridae). Mar. Biol. 90: 317-326

Victor, B. C. (1986b). Delayed metamorphosis with reduced larval growth in a coral reef fish, Thalassoma bifasciatum. Can. J. Fish. Aquat. Sci. 43: 1208-1213

Wellington, G. M., Victor, B. C. (1989). Planktonic larval duration of one hundred species of Pacific and Atlantic damselfishes (Pomacentridae). Mar. Biol. 101: 557-567

Zar, J. H. (1984). Biostatistical analysis. Prentice-Hall, Inc., New Jersey

Manuscript first received: March 29, 1990

Revised version accepted: September 28, 1990 